\title{
PENGARUH PENAMBAHAN LIMBAH ABU BATU TERHADAP KUAT BETON Fc'20 Mpa DENGAN MENGGUNAKAN GRADASI SPLIT BERBEDA
}

\author{
Asrullah $^{1)}$, Cecep Irwansyah ${ }^{2)}$, Mupli $^{3)}$ \\ ${ }^{1)}$ Dosen tetap YPTP pada Prodi. T. Sipil Universitas Palembang, \\ ${ }^{2)}$ BBPJN Sum Sel, Kementerian PU dan Perumahan Rakyat, ${ }^{3)}$ Mahasiswa Universitas Palembang \\ Email: ${ }^{1}$ Asrull66@yahoo.co.id
}

\begin{abstract}
Abstrak
Industri beton di Indonesia sudah sangat maju dan berkembang. Maka penggunaan material konstruksi menjadi semakin meningkat. Dibutuhkan material lain sebagai pengganti agregat halus untuk pembuatan beton. Salah satu bahan yang dapat digunakan adalah abu batu yang berasal dari limbah industri batu belah. Metode yang digunakan dala desain campuran beton menggunakan SNI 03-2834-2000. Tujuan dari penelitian ini untuk mengetahui nilai kuat tekan beton normal, beton, nilai kuat tekan beton dengan penambahan Abu Batu 1\%,2\% dan 3\% dari berat pasir. Nilai kuat tekan beton Normal sebesar 20,4 MPa memenuhi standar perencanaan yaitu $20 \mathrm{MPa}$. Nilai kuat tekan beton dengan penambahan abu batu $1 \%$ sebesar 22,4 MPa, nilai kuat tekan beton dengan penambahan abu batu 2\% sebesar 23,3 MPa dan nilai kuat tekan beton dengan penambahan abu batu $3 \%$ sebesar $24,8 \mathrm{MPa}$.
\end{abstract}

Kata Kunci : Kuat Tekan, Abu Batu, Nilai Slump, Regresi Linier

The concrete industry in Indonesia is very advanced and growing. So the use of construction materials is increasing. Other materials are needed as a substitute for fine aggregate for the manufacture of concrete. One of the materials that can be used is stone ash that comes from the waste stone industry. The method used in the design of concrete mix using SNI 03-2834-2000. The purpose of this study was to determine the compressive strength of normal concrete, concrete, the value of the compressive strength of concrete with the addition of $1 \%, 2 \%$ and $3 \%$ of stone ash by weight of sand. Normal concrete compressive strength value of $20.4 \mathrm{MPa}$ meets the planning standard of $20 \mathrm{MPa}$. The value of the compressive strength of concrete with the addition of $1 \%$ stone ash is $22.4 \mathrm{MPa}$, the value of the compressive strength of concrete with the addition of $2 \%$ stone ash is $23.3 \mathrm{MPa}$ and the compressive strength value of concrete with the addition of $3 \%$ rock ash is $24.8 \mathrm{MPa}$.

\section{PENDAhuluaN}

Industri beton di Indonesia sudah sangat maju dan berkembang. Maka penggunaan material konstruksi menjadi semakin meningkat. Dibutuhkan material lain sebagai pengganti agregat halus untuk pembuatan beton. Salah satu bahan yang dapat digunakan adalah abu batu yang berasal dari limbah industri batu belah. Dari penelitian yang dilakukan oleh [1] dimana terjadi peningkatan kuat tekan beton dengan penambahan Abu Batu pada setiap komposisi campuran.

Penelitian-penelitian telah banyak dilakukan untuk memperoleh suatu penemuan alternatif penggunaan konstruksi karenabeton merupakan unsur yang sangat penting, mengingat fungsinya sebagai salah satu pembentukstruktur yang paling banyak digunakan oleh masyarakat. Keadaan ini dapat dimaklumi, karena sistem konstruksi beton mempunyai banyak kelebihan jika dibandingkan dengan bahan lain. Keunggulan beton sebagai bahan konstruksi antara lain mempunyai kuat tekan yang tinggi, dapat mengikuti bentuk bangunan secara bebas, tahan terhadap api dan biaya perawatan yang relatif murah.

Hal lain yang mendasari pemilihan dan penggunaan beton sebagai bahan konstruksi adalah faktor efektifitas dan tingkat efisiensinya. Secara umum bahan pengisis (filler) beton terbuat dari bahan-bahan yang mudah diperoleh, mudah diolah (workability) dan mempunyai keawetan (durability) serta kekuatan (strenght) yang sangat diperlukan 
dalam pembangunan suatu konstruksi.Beton juga mempunyai beberapa kelemahan, yaitu lemah terhadap kuat tarik, mengembang dan menyusut bila terjadi perubahan suhu, sulit kedap air secara sempurna, dan bersifat getas pembentukannya, serta lebih tahan terhadap korosi dan temperatur tinggi jika dibandingkan dengan baja [2].

\section{KAJIAN PUSTAKA}

Beton adalah sebuah bahan bangunan komposit yang terbuat dari kombinasi bahan pengikat (pada umumnya terdiri dari semen hidrolis dan air), agregat halus (pasir), dan agregat kasar (koral/batu pecah) dengan atau tanpa bahan tambahan (SNI 03-2847-2013). Sifat beton dipengaruhi oleh bahan pembentuknya serta cara membuatannya. Semen berfungsi sebagai pengikat beton itu sendiri. Untuk kadar umpur, gradasi, berat jenis agregat mempengaruhi kekuatan beton [3] Menurut [4] gradasi agregat halus mempengaruhi pengerjaanya, sedangkan agregat kasar mempengaruhi kekuatan beton. Kualitas dan kuantitas air mempengaruhi pengerasan dan kekuatan beton.

Dalam suatu proses pembuatan beton, yang perlu diperhatikan adalah kekuatan, keekonomisan, dan durabilitas bahan dari beton tersebut. Durabilitas adalah daya tahan suatu bahan terhadap beban yang akan diterimanya. Pembuatan beton melalui proses perhitungan kadar air, jumlah semen dan jumlah agregat yang diperlukan. Setelah proses perhitungan, akan dilakukan proses pembuatan beton dengan bahan-bahan yang telah dihitung. Setelah beton terbentuk, dilakukanlah proses perawatan selama 28 hari. Seiring dengan mencapainya umur beton, maka beton akan semakin mengeras dan akan mencapai kekuatan rencana $\left(\mathrm{f}^{\prime} \mathrm{c}\right)$. Pada saat keras, beton diharapkan mampu memikul beban sesuai rencana sehingga sifat utama yang harus dimiliki oleh beton adalah kekuatannya [5]. Abu batu merupakan hasil penggerusan dari produksi batu pecah. Abu batu merupakan abu yang mengandung banyak silika, alumina dan mengandung senyawa alkali, besi, dan kapur walaupun dalam kadar yang rendah. Dari setiap daerah, komposisi abu batu digunakan dalam adukan beton terutama untuk memperbaiki sifat dari beton. Pemakaian abu batu dapat menghemat pemakaian semen. Abu. batu mengandung senyawa silika yang sangat halus yang bersifat amorf sehingga mampu mengeras bila dicampur dengan semen. Senyawa yang terjadi. antara silika amorf dan kapur adalah senyawa silikat kalsium yang sukar larut dalam air. Kemampuan pengerasan dari abu batu karena adanya bagian-bagian silika amorf yang halus [5].

Analisa regresi linier sederhana dilakukan untuk memperoleh suatu model regresi yang menggambarkan hubungan antara satu variabel bebas (penambahan Abu Batu) dan suatu variabel terikat (kuat tekan beton) [6]. Dalam penelitian ini yang menjadi variabel bebas (X) adalah penambahan Abu Batu, sedangkan variabel terikat $(\mathrm{Y})$ adalah kuat tekan beton.

\section{METODOLOGI PENELITIAN}

Penelitian ini merupakan suatu eksperimen (percobaan) di laboratorium UPTD Laboratorium Dinas PU Bina Marga dan Tata Ruang Provinsi Sumatera Selatan yang dilakukan untuk mengetahui pengaruh penambahan Abu Batu terhadap kuat tekan beton. Pengujian material meliputi pengujian berat jenis, kadar air agregat, kadar lumpur agregat, analisa saringan, modulus kehalusan, berat jenis agregat, dan penyerapan agregat (halus \& kasar) [4]. Mix desain mengikuti SNI 03-2834-2000 [8] untuk beton normal, serta beton campuran dengan tambahan abu batu $1 \%, 2 \%, 3 \%$ dari berat pasir. Abu batu yang digunakan adalah batu yang berasal dari PT. Comba Mahaka Utama desa Lingut OKUT.

Proporsi abu batu pada campuran beton $1 \%, 2 \%$ dan 3\%dari berat pasir. Kuat tekan beton yang direncankan mutu $F c^{\prime} 20 \mathrm{Mpa}$ (mutu minimum). Slump direncanakan dengan motede SNI 1972-2008 [9]. Tes kuat tekan beton umur 7,14,21 dan 28 hari dengan metode SNI 1974-2011, cetakan benda uji kubus $25 \times 25 \times 25 \mathrm{~cm}$ [10]. material beton terdiri dari agregat kasar (split) ex Lingut, Agrgat Halus (Pasir) dari ex Indralaya Ogan Ilir, Air dari PDAM, Abu Batu ex Stone Crusser PT. Comba Mahaka Utama OKUT. 


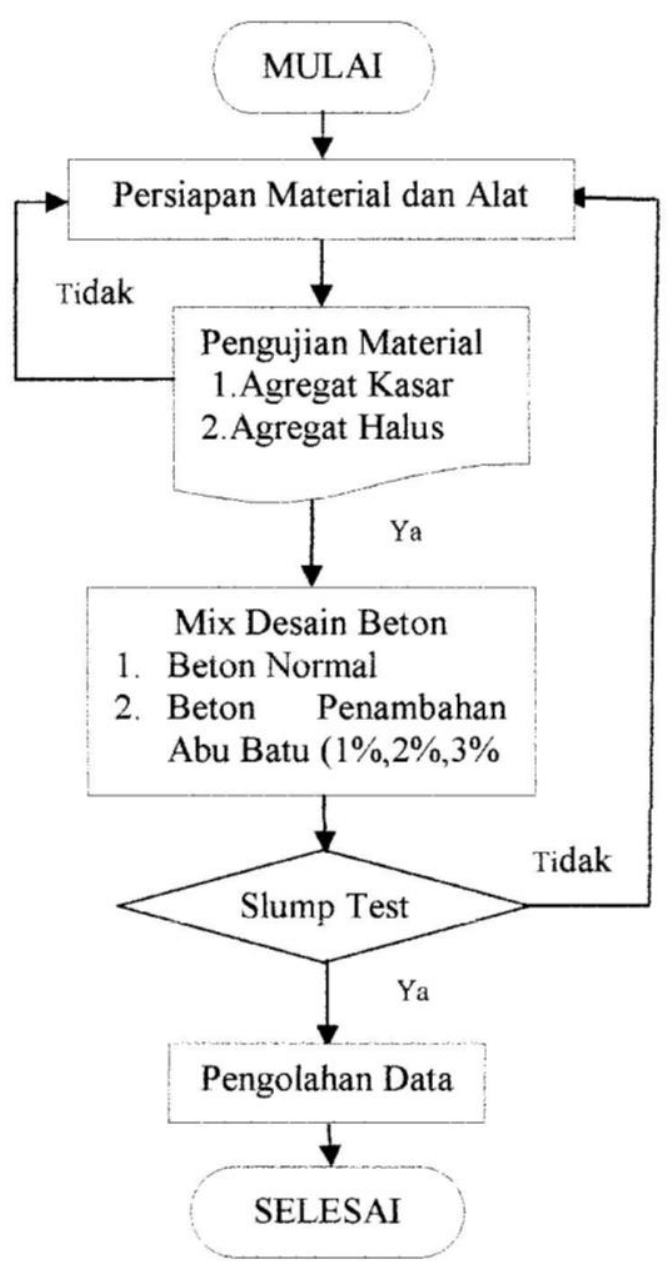

Gambar 1. Bagan Alir Penelitian

\section{HASIL DAN PEMBAHASAN}

\subsection{Hasil Pengujian Agregat Halus dan}

\section{Kasar}

Hasill pengujian karakteristik agregat halus dan kasar disajikan dalam tabel 1 berikut ini.
Tabel 1. Nilai Karakteristik

Agregat Halus dan Kasar

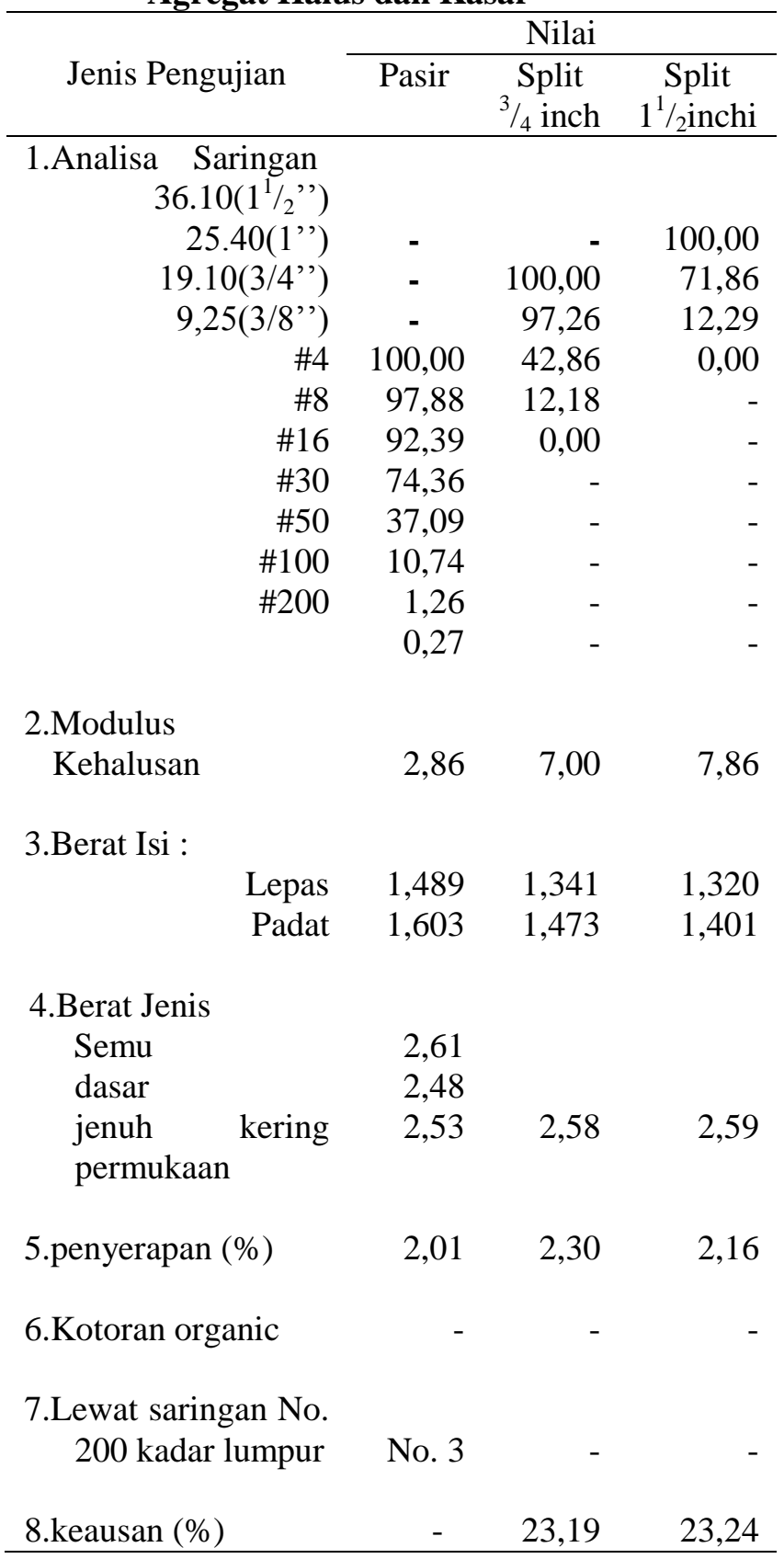

\subsection{Komposisi Campuran Beton}

Kebutuhan material beton dengan menggunakan metode SNI 03-2834-2000 disajikan pada tabel 2 berikut ini : 
Tabel 1. Keebutuhan Material Untuk $1 \mathrm{M}^{3}$ Beton

\begin{tabular}{llr}
\hline No & \multicolumn{1}{c}{ Jenis Material } & \multicolumn{1}{c}{$\begin{array}{c}\text { Kebutuhan } \\
\text { Material Untuk } \\
1 \mathrm{M}^{3} \text { Beton }\end{array}$} \\
\hline 1 & $\begin{array}{l}\text { Semen } \\
2\end{array}$ & $\begin{array}{l}\text { Pasir } \\
\text { Split Ukuran }\end{array}$ \\
3 & $\begin{array}{l}3 / 4 \\
(19,00 \mathrm{~kg})\end{array}$ \\
4 & $\begin{array}{l}\text { Split ukuran 1/2 inchi } \\
(37,50 \mathrm{~mm})\end{array}$ \\
5 & $\begin{array}{l}\text { Air PDAM } \\
\text { Abu Batu 1\% dari }\end{array}$ & $673 \mathrm{~kg}$ \\
& $\begin{array}{l}\text { Berat Pasir } \\
\text { Abu Batu 2 \% dari } \\
\text { berat pasir } \\
\text { Abu Batu 3 \% dari } \\
\text { berat pasir }\end{array}$ & $18,51 \mathrm{ltr}$ \\
& $6,31 \mathrm{~kg}$ \\
& $12,62 \mathrm{~kg}$ \\
\end{tabular}

\subsection{NILAI SLUMP}

Pengujian nilai slump dilakukan setiap jenis campuran beton, hasil pengujian nilai slump beton disajikan pada tabel 3 berikut ini.

Tabel 3 Nilai Slump Berbagai Variasi Komposisi

\begin{tabular}{clc}
\hline No & \multicolumn{1}{c}{ Jenis Beton } & $\begin{array}{c}\text { Nilai } \\
\text { Slump } \\
(\mathrm{mm})\end{array}$ \\
\hline 1 & $\begin{array}{l}\text { Beton Normal Tanpa } \\
\text { Penambah Abu Batu }\end{array}$ & 82 \\
2 & $\begin{array}{l}\text { Beton dengan Penabahan Abu } \\
\text { Batu 1\% }\end{array}$ & 79 \\
3 & $\begin{array}{l}\text { Beton dengan Penabahan Abu } \\
\text { Batu 2\% }\end{array}$ & 76 \\
Beton dengan Penabahan Abu \\
Batu 3\%
\end{tabular}

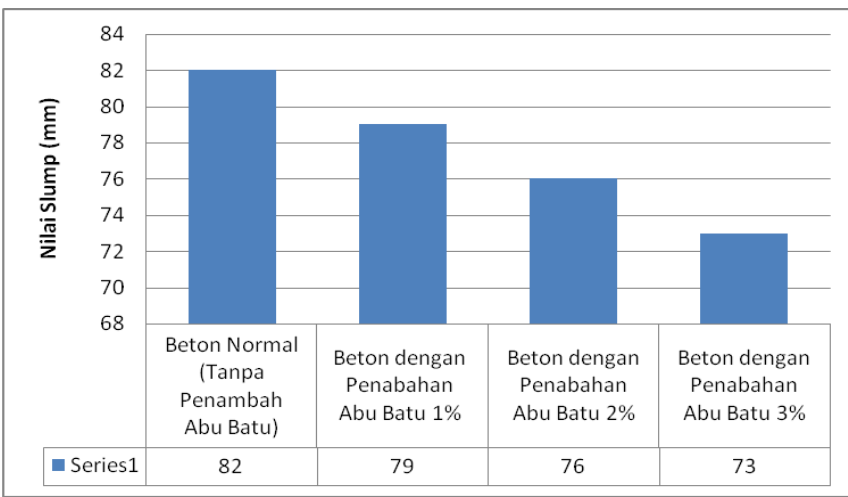

Gambar 2. Nilai Slump Berbagai Variasi Komposisi
Hasil yang disajikan pada tabel 3, dapat disimpulkan dengan bertambahnya Abu Batu di dalam campuran beton, maka nilai slump terjadi penurunan. dari $82 \mathrm{~mm}$ secara berturutturut menurun menjadi $79 \mathrm{~mm}, 76 \mathrm{~mm}, 73$ $\mathrm{mm}$. Untuk penambahan Abu batu memenuhi syarat yang ditetapkan yaitu nilai slump harus berada pada rentang 100-60 mm [9]. Menurut Asrullah [7] penurunan nilai slump ini dikarenakan adanya peningkatan penambahan jumlah Abu Batu dalam campuran beton sedangkan jumlah air tetap, sehingga campuran beton menjadi kental dan cenderung tidak homogen.

\subsection{Hasil Pengujian Kuat Tekan}

Hasil pengujian kuat tekan beton karakteristikpada umur 28 hari setiap campuran disajikan dalam tabel 4 berikut ini.

Tabel 4. Kuat Tekan Beton Beton Umur 28 Hari

\begin{tabular}{clc}
\hline No & \multicolumn{1}{c}{ Jenis Beton } & $\begin{array}{c}\text { Kuat Tekan } \\
\text { (MPa) }\end{array}$ \\
\hline 1 & $\begin{array}{l}\text { Beton Normal (Tanpa } \\
\text { Penambah Abu Batu) }\end{array}$ & 20,40 \\
2 & $\begin{array}{l}\text { Beton dengan Penabahan } \\
\text { Abu Batu 1\% }\end{array}$ & 22,80 \\
3 & $\begin{array}{l}\text { Beton dengan Penabahan } \\
\text { Abu Batu 2\% }\end{array}$ & 23,30 \\
4 & $\begin{array}{l}\text { Beton dengan Penabahan } \\
\text { Abu Batu 3\% }\end{array}$ & 24,80 \\
\hline
\end{tabular}

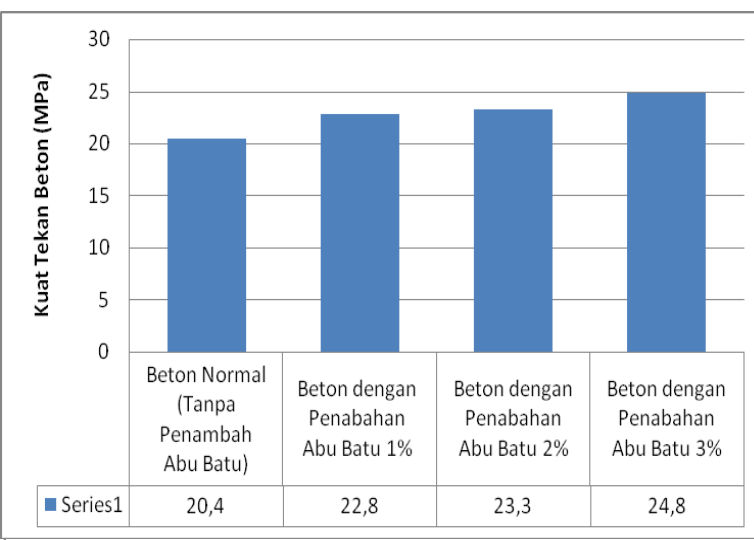

Gambar 3. Nilai Kuat Tekan Beton Berbagai Variasi Komposisi

Hasil yang disajikan pada tabel 4, dapat disimpulkan dengan bertambahnya Abu Batu di dalam campuran beton, maka nilai kuat tekan terjadi peningkatan. 20,4 MPa untuk beton normal secara berturut-turut terjadi 
peningkatan menjadi 22,4 $\mathrm{MPa}$ untuk kuat tekan beton dengan penambahan abu batu $1 \%$, 23,3 MPa untuk kuat tekan beton dengan penambahan abu batu 2\%, dan 24,8 MPa untuk kuat tekan beton dengan penambahan abu batu 3\%. Dari penelitian ini menyimpulkan bahwa dengan penambahan Abu Batu dapat meningkatkan kuat tekan beton ini sesuai dengan hasil penelitian [1] Penggunaan abu batu sebagai bahan tambah pada beton akan meningkatkan kuat tekan beton sebesar jika dibandingkan dengan kuat tekan beton yang tidak menggunakan abu batu.

\subsection{Model Hubungan Regresi Linier Sederhana}

Analisa regresi linier sederhana dilakukan untuk memperoleh suatu model regresi yang menggambarkan hubungan antara suatu variabel bebas (X) (penambahan abu batu) dan suatu variabel terikat (Y) kuat tekan beton. Hasil Analisa regresi disajikan pada gambar 4 dan 5 berikut ini.

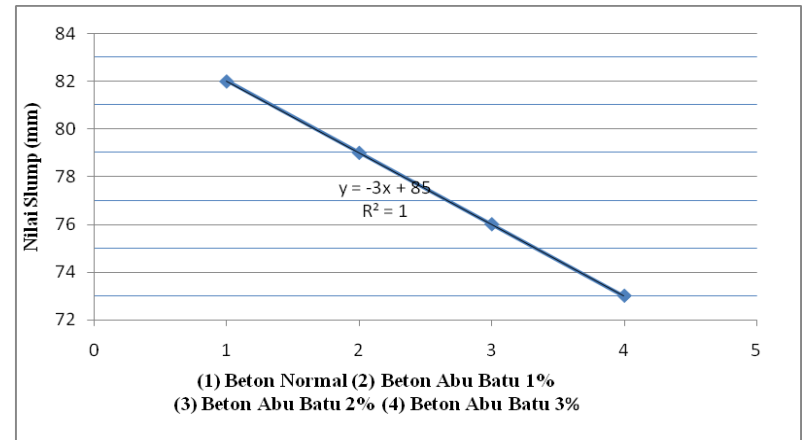

Gambar 4. Hubungan Nilai Slump Beton Dengan Penambahan Abu Batu

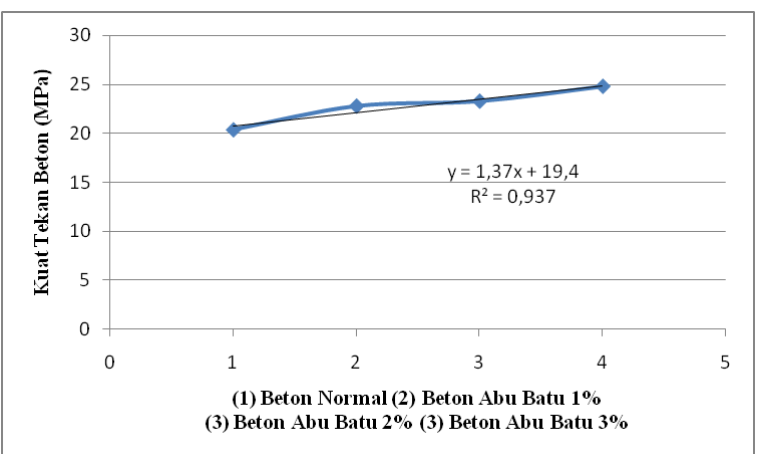

Gambar 5. Hubungan Nilai Kuat Tekan Beton Dengan Penambahan Abu Batu

Model regresi pada Gambar 4 adalah regresi linier sederhana yang merupakan hubungan antara nilai slump beton dengan penambahan Abu Batu dengan persamaan $\mathrm{Y}=$
$-3 \mathrm{x}+85$. Dari persamaan ini terlihat bahwa nilai minus Asrullah dalam [6] pada koefisien regresi menunjukkan angka penurunan variabel terikat $(\mathrm{Y})$ yang didasarkan pada variabel bebas (X). Artinya jika penambahan Abu Batu meningkat, maka akan menyebabkan penurunan nilai slump. Selanjutnya menurut Asrullah dalam [6] koefisien determinasi $\mathrm{R}^{2}$ bernilai 1 , berarti memeliki keterkaitan yang kuat antara penambahan Abu Batu dan nilai slump beton. Selain itu koefisien tersebut memperlihatkan bahwa pengaruh penambahan Abu Batu terhadap nilai slump sebesar $100 \%$.

Model regresi pada Gambar 5 adalah regresi linier sederhana yang merupakan hubungan antara nilai kuat tekan beton dengan penambahan Abu Batu dengan persamaan $\mathrm{Y}=$ $1,37 x+19,4$. Dari persamaan ini terlihat bahwa nilai positif Asrullah [6] pada koefisien regresi menunjukkan angka peningkatan variabel terikat (Y) yang didasarkan pada variabel bebas (X).

Artinya jika penambahan Abu Batu meningkat, maka akan menyebabkan peningkatan nilai kuat tekan beton. Selanjutnya menurut Asrullah [6] koefisien determinasi $\mathrm{R}^{2}$ bernilai 0,937 , berarti memeliki keterkaitan yang kuat antara penambahan Abu Batu dan nilai kuat tekan beton. Selain itu koefisien tersebut memperlihatkan bahwa pengaruh penambahan Abu Batu terhadap nilai kuat tekan beton sebesar $93,70 \%$.

\section{KESIMPULAN DAN SARAN}

\section{A. Kesimpulan}

Dari hasil penelitian ini dapat disimpulkan sebagai berikut.

1. Nilai kuat tekan beton Normal sebesar 20,4 MPa memenuhi standar perencanaan yaitu $20 \mathrm{MPa}$.

2. Nilai kuat tekan beton dengan penambahan abu batu $1 \%$ sebesar 22,4 $\mathrm{MPa}$

3. Nilai kuat tekan beton dengan penambahan abu batu $2 \%$ sebesar 23,3 $\mathrm{MPa}$

4. Nilai kuat tekan beton dengan penambahan abu batu $3 \%$ sebesar 24,8 MPa. 


\section{B. Saran-saran}

Dari hasil yang ada, maka peneliti memberikan saran-saran sebagai berikut :

1. Usahakan adanya penelitian lanjutan.

2. Dalam penelitian lanjutan dilakukan penamahan jumlah Abu Batu dalam campuran beton sehingga dapat ditemukan persentasi yang maksimum dalam penambahan abu batu.

\section{DAFTAR PUSTAKA}

[1] Triaswati M.N, Didik Harijanto, Boedi Wibowo \& Wahyu Ismoyo, 2019 Use of Rock Ash to Reduce Natural Sand Aggregates in Concrete Mixes by Adding Type D Additive Substances Departemen Teknik Infrastruktur Sipil, Fakultas Vokasi, (ITS). Surabaya. (e)ISSN 2615-1847 (p)ISSN 26151839 Jurnal Manajemen Aset Infrastruktur \& Fasilitas, Vol. 3, Edisi Khusus 2, Juni 2019 pp 1-9.

[2] Tjokrodimuljo K.1996, Teknologo Beton Nafiri Yoyakarta.

[3] SNI 03-2847-2013. Tata Cara Perencanaan Struktur Beton Untuk Bangunan Gedung. Jakarta: Badan Standarisasi Nasional.

[4] Murdock, L.J. \& K.M.Brook 1979, Bahan dan Praktek Beton Ed ke 4, Cet.ke 3, Erlangga Jakarta ISBN 32-00-038-2.

[5] Tanjung Rahayu Raswitaningrum, Randy Fajar Aris Setiawan, 2019. Pengaruh Abu Batu Terhadap Kuat Tekan Beton Pasca Pembakaran Program Studi Teknik Sipil, Universitas Muhammadiyah Jakarta, Jakar Jl. Cempaka Putih Tengah XXVII p-ISSN : 2407-1846 e-ISSN : 2460-8416 Website : jurnal.umj.ac.id/index.php/semnastek

[6] Asrullah and A Mulyadi, 2017. A Study on the Use of Mortar Utama Cement Type 420 as Concrete Admixture. International Conference on Innovative Research ICIR EUROINVENT 2017 IOP Publishing IOP Conf. Series: Materials Science and Engineering 209 (2017) 012088 doi:10.1088/1757899X/209/1/012088.pp.7

[7] Asrullah 2015, Concrete Strength Analysis K 250 With Addition of Mortar Utama Cement Type 420 With Rough Aggregate Size (Split) Uniform,
Journal of Civil Engineering Program Study, Engineering Faculty, University of Palembang. Volume 5, Number 10, September 2015 ISSN 2089-2950, pp 9-20.

[8] SNI 63-2834-2000. Tata Cara Pembuatan Campuran Beton Normal.

[9] SNI 1972-2008. Tata Cara Slump Beton. [10] SNI 1974-2011. Cara Uji Kuat Tekan Beton Dengan Benda uji Kubus 